\title{
Network nominations of media communication participants in the modern Russian language
}

\author{
A. A. Malyshev \\ St. Petersburg State University, \\ 26, 1-ya Liniya V. O., St. Petersburg, 199004, Russian Federation
}

For citation: Malyshev, A.A. (2018). Network nominations of media communication participants in the modern Russian language. Media Linguistics, 5 (3), 339-345. https://doi.org/10.21638/ spbu22.2018.307

The paper is dedicated to the analyses of the modern media communication participants' nomination examples as a live speech-creating process occurring in the computer-mediated discourse of the Internet, i.e. in a virtualized social space characterized by the desire to make the dialogue between the communicants maximally close. Interactivity and the involvement of all participants of network interaction into the creation of media content lead to the decentralization of communication and the transformation of the object of media communication into a full-fledged subject and creates the equality of the addressee and addresser. The convergent space of a modern media sphere which definites the media communication participants' choice of certain speech behavior models is characterized by a specific hierarchy of communicants' relations within the subject - object or the subject - subject dialogical interaction. Communication in the cognitive specific environment of media-reality allows the users to comprehend and to terminologically determine the role of each personality from the network space (both already known and met for the first time). According to this fact it is difficult to define the place of the subject of media communication in the opposition "the dilettante - the professional" and to qualify it's nomination as the nomination of the general sort or as the professionally caused nomination what is caused by the most discursive environment of the media reality existence. On this basis, there are three types of a speech personality nomination depending on the nominated subject's role-determined participation in the process of cognitive identification (identification "from inside", representation "from outside", self-determination). The paper questions the duality of the use of individual nominations due to the influence of political and ideological aspects in the evaluating naming of the action that is a means of establishing contact with the audience. Special attention is paid to the degree of professional involvement of media communication subjects in media reality and the formation of the negative connotations with a number of communicants' denominations because of the characteristics of their network behavior.

Keywords: media communication, network communication, media linguistics, virtual society.

Statement of the problem. Transfer of traditional forms of communication into the "convergent synthetic space of the social relations, communicative actions and media activity" [Blokhin 2016: 255] has led to the transformation of the existing social roles of communication participants [Gavra 2005-2006; Issers 2012]. The considerable "distance" communicative separation of printed and audiovisual media staff and their readers, audience and listeners was replaced by a possibility of direct and live online communication

(c) Санкт-Петербургский государственный университет, 2018 
between the journalist and the audience via comments to the written text [Internet-kommunicatsiia... 2012; Gorina 2016]. The role of the subject - object interaction addressee's interactivity and involvement in creation of media content existing in network in the form of hypertext has considerably increased [Ryazantseva 2010; Shchipitsina 2010]. In certain cases it leads to the decentralization of communication and to the transformation of the object of media communication into a full-fledged subject (the subject - subject interaction). Actually the relations between communicants remained the same: the sender and the addressee, the journalist and the audience, the author and the reader, the speaker and the listener, i.e. in a broad sense, there is a certain sender and a certain recipient of the message, however, the role base of their behavior in a media sphere have undergone some quality changes that was also reflected in the media communication subject's nominations.

Background. Studying of media communication subjects' nominations in the digital environment is traditionally conducted in line with the research of both assimilation of English computer slang and the speech-creative potential of the Russian language in the Russian Internet communication of the 1990s and the beginning of the 2000s which took place at forums and imageboards [Likholitov 1997; Kutuzov 2006; Maksimova 2010; Guseinov 2014]. D. V. Ivanov thoroughly studied the sources of this process which started with social computerization promoting rapid virtualization of society [Ivanov 2002].

Material analysis. The virtualization of society brought about the formation of the media reality [Polonsky 2016] which caused the transformation of professional activity forms (a designer - a web-designer, a consultant - an Internet consultant, a political strategist - a web-political strategist, etc.) and the emergence of "professions" connected with monetization of network activity (an Instagram model, a video blogger, a gamer, a webcam-model, a streamer, etc.). In this regard, the phenomenon of priests working in the Worldwide network (so-called "Internet fathers"), preaching on the Internet and absolving sins via online and offline confession is extremely curious. The modern principles of receiving and dissemination of information led, among other things, to the emergence of such nominations as pranker 'a person who obtains information by means of a prank call (manipulative telephone or Internet joke)' and faker ' a creator and/or a distributor of fakes, i.e. counterfeit (news) information' [Ilchenko 2016].

At the same time, the question of the degree of communicative activity professionalizing in Network is to be discussed: for example, whether video blogging is really a job or only a simple hobby, an occupation accompanied with a certain income (about formation of of the professional person category, its features and the linguistic form, see: [Golovanova 2004; Iakovleva 2009]). Therefore, in certain cases, it seems difficult to define the place of a media communication subject in opposition "an amateur - a professional" and to qualify its nomination as the nomination of a general sort or as a professionally associated nomination. Thus, in general understanding the subject of the media speech is the author of posts, texts and articles, and its identification by this or that nomination is generated by the discourse environment of the person's existence itself.

Some of the nominations have become outdated, and now they are used seldom or restrictedly in media communication: тамер (lamer) - for designation of an incompetent self-confident computer user; нуб (nоob), ньюбаг (newfag) and чайник (chainick, i.e. newbie) - for designation of an Internet new-comer; красноглазик (krasnoglazick, i.e. red-eyer) - for the users writing in the Internet at night because of the lower cost of night traffic, they have red eyes after the sleepless night; бumapd (/b/tard) - for designation of 
the frequenter of popular sections of imageboard, etc. The communicative popularity and rate gradually decrease for such nominations as

- юзер (user 'Internet user'; spelling options ouser, usver' and usverg to name the beginner as ouser or the experienced user as usverg; they are replaced by the original word пользователь / polzovatel' as a neutral word for 'user' in Russian);

- смайлофаг (smileyfag) and смайлофил (smileyphil) 'the user who loves various smilies and emojies';

- кармадрочер (karmadrocher) 'karmafapper, the user with painful reverence for the network reputation expressed by pluses, likes, etc.;

- хомячок (khomyatchock, i.e. little hamster) 'a trustful user who is easily giving in to manipulation';

- падонак (padonak) 'a geek-user intentionally breaking spelling standards of Russian (like 'authar', 'hullou', 'vrite moore').

The nomination модератор (moderator) 'the user given authority for rules observance management' remains mainly the achievement of forum communication. The nomination спамер (spammer) 'the user distributing advertizing messages by e-mail and in large quantities, leaving them at forums and in social networks' is strictly limited. The modern network nominations of media communication subjects in Russian are formed on the same grammatical models and go through similar stages of semantic adaptation which need various time for each new nomination.

When generally discussing a media communication subject as an information media language personality, the point is either about a certain type of a media figure (a journalist, a writer, a politician, a blogger, etc.) or about a person of syncretic type embodying certain discourse settings in a certain cognitive style [Bolotnova 2017: 10-65]. In this case the concept "subject of media communication" is accepted for analysis as an indivisible part of media communication shown for the research in a finished form and in role behavior stability.

At the same time it is possible to allocate three types of nomination of such a language personality, because in the media reality there is a semantic differentiation of key nominations of a media communication subject in the course of network communication (each type can be considered both in real and in imaginary aspect):

1. The identification nomination, which is carried out by participants of communication directly in the course of communication ("everyone knows everyone" communication type). For example, the nomination тролль (troll) by the identification nomination designates a user who is intentionally carrying out the provocative destructive activity aiming at violation of other users' personal comfort space for the purpose of receiving moral satisfaction (about methods of trolling in media see: [Duskayeva, Konyaeva 2017]). Trolling, by definition of communication participants, can be 'thick' (rough explicit provocation which is rather obvious for potential victims) and 'thin' (masterful use of the disguised rhetorical receptions, balance on the verge of violation of the rules adopted in this Internet resource). Different types of trolls are allocated (a troll adviser, an asking troll, a troll know-it-all, a sexual troll, a troll-parent, a troll-pensioner, etc.). The troll who is acting only in his own interests should be nominatively distinguished from the provoker or so-called зажигалка (zazhigalka, i.e. trigger) whose activity can be approved by moderators of forums and social nets, because they sort of "provoke" users softly and bring 
benefit to the website in the form of Internet traffic, the number of viewings and posts thus increasing the level of attendance.

2. The self-identification nomination is connected with a communicative self-feeling of the media communication subject. Using self-identification nomination, the user can resolutely protest against his recognition as a troll (because in his mind, the concept of trolling has a negative connotation) or recognize the full legitimacy of this definition with obvious satisfaction and even pride (no wonder, western researches quite often describe troll as a psychotype [Hardaker 2010; Van Reenen 2013; Buckels, Paulhus, Trapnell 2014; Cheng, Danescu-Niculescu-Mizil, Leskovec 2014]). Similarly, a user indulged into active writing or video activity in the blogosphere is ordinary designated by nomination блогер (blogger) or video blogger (влогер / vlogger), yet, due to the conceptual convergence, the person can sincerely consider himself to be a true journalist, not even having the special journalist education.

3. The representation nomination is based on viewing the subject of media communication "from outside", when there is a need to introduce the person to the audience (guest type of communication) or to characterize someone's activity in a certain communicative situation. This type of nomination can lead to the shift of semantic accents. We can see such examples in the ideologically formulated media headlines: Vladimir Putin trolled Poroshenko and Putin trolled the American democrats for the A-mark - the designation of the Russian President's actions as trolling is enthusiastically approved and positively assessed. Similar is the case with the nomination of a political strategist Anna Fedorova in material of the female magazine "Wonderzine": she was called nолиттехнологесса (polittechnologesse) which can be considered as an obvious example of flirting with feminists' audience (Anna Fedorova herself doesn't use the feminizing suffix for self-determination).

In many cases the nomination of the media communication subject contains a negative semantic component and is used in the pejorative function: for example the professional копирайтер (copywriter) and the pejorative копираст (copyrast). The nomination болудер (flooder) describes a user leaving a large number of senseless and/or identical messages, but not aiming at offending someone; though flood can be considered as the predecessor of trolling, compare with brightly negative gorydepacm (flooderast). The nomination фолеймер (flamer) designating a dispute adopt for the sake of dispute itself even if polemic leaves the main discussion limits is seldom used though the phenomenon of a flame is rather widespread. Similar is the situation with the nomination og 6 monep (offtopper 'the user leaving posts out of the discussion subject') and a concept oбббтопинг (off topping) as the process designation. In its destructive potential, troll is really similar to $60 m$ (bot) nomination 'a user whose actions remind of a computer program work, who is mechanically producing messages according to the set algorithm, whose purpose is bringing discussion to the actual impossibility of further communication' (similar mechanisms are used for "muting" discussions in network devoted to acute socio-political questions). A kind of destructive communication is combination of trolling with mechanicalness, which subject is designated by троллебот (trollebot) nomination (like the activity of St. Petersburg "factory of trolls", which provoked a considerable political public response, or the so-called "Kremlin trolls", i.e. the participants of media communication showing purposeful destructive Internet activity not due to some personal features, but on a commercial basis). 
Nominations designating a kind of activity, constructive in its nature, or positive vital installations also have negative semantics. Such nominations develop in case of unlimited and unilateral activity of the media communication subject: e.g., зожник (zozhnik) a person-supporter of a healthy lifestyle (zdorovyj obraz zhizni) and фитонячка (fitonyashka) 'a pretty girl who does fitness actively' - in both cases the excessively categorical promotion of the useful activity has led to ironic reconsideration of the nominations. The nominations designating activity in Instagram network also may be ironical: инстаграммщзица (instagramshchitsa) 'a girl fixing each her action in Instagram with comical meticulousness', similarly - insta-mother, insta-wife, insta-daughter, etc. (there is a tendency of more often usage of "male" analogs: instagramshchik 'insta-guy', instafather, insta-husband, insta-son, etc.). The irony is amplified by addition of a venomous epithet typical to the corresponding nomination. The new "profession" noted above get an important problem with people's perception: e.g., an insta-model / insta-star is quite often exposed to a derision as a pseudo-activity (see the corresponding Internet memes and demotivators), because to get this profession, as sneering people think, it is enough to have only a pretty look in the absence of intellectual efforts, i.e. the insta-model has no special knowledge or professional skills acquired in the course of training, which distinguish this kind of activity as the professional one in public consciousness [Golovanova 2004].

Conclusions. The communicative potential of the media communication subject's network nomination differs in a variety of discursive characteristics, dynamics and variability of semantic filling and is of a particular scientific interest as one of the brightest manifestations of mediatization of the modern people's life.

\section{References}

Blokhin, I. N. (2016). Lichnost'v prostranstve massovoi kommunikatsii: nachala rolevogo analiza [The personality in space of mass communication: the basis of the role analysis]. St. Petersburg. (In Russian)

Bolotnova N.S. (Ed.). (2017). Iazykovaia lichnost' i mediasreda: kommunikativno-kognitivnye aspekty vzaimodeistviia [Language personality and mediasreda: communicative and cognitive aspects of interaction]. Tomsk. (In Russian)

Buckels, E., Paulhus, D., Trapnell, P. (2014). Trolls just want to have fun. Personality and Individual Differences, 67, 97-102.

Cheng, J., Danescu-Niculescu-Mizil, C., Leskovec, J. (2014). Antisocial Behavior in Online Discussion Communities. Retrieved from https://timedotcom.files.wordpress.com/2015/04/1504.00680v1.pdf.

Duskaeva, L. R., Koniaeva, Iu. M. (2017). Trolling v russkoiazychnykh media [Trolling in Russian-language media]. Vestnik MGU (Seriia Zhurnalistika) [Moscow University Journalism Bulletin], 5, 84-100. (In Russian)

Gavra, D. P. (2005-2006). Osnovy teorii kommunikatsii [Bases of the theory of communication]. Vol.1-2. St. Petersburg. (In Russian)

Golovanova, E. I. (2004). Kategoriia professional'nogo deiatelia v dinamicheskom prostranstve iazyka: Lingvokognitivnyi analiz [Category of the professional figure in dynamic space of language: Linguo-cognitive analysis]. $\mathrm{PhD}$ thesis. Chelyabinsk. (In Russian)

Gorina, E. V. (2016). Konstituiruiushchie priznaki diskursa Interneta [The constituting signs of a discourse of the Internet]. PhD thesis. Yekaterinburg. (In Russian)

Guseinov, G. Ch. (Eds.). (2014). Russkii iazyk i novye tekhnologii [Russian language and new technologies]. Moscow. (In Russian)

Hardaker, C. Trolling in Asynchronous Computer-Mediated Communication: From User Discussions to Academic Definitions. Journal of Politeness Research: Language, Behavior, Culture, 6 (2), 215-242.

Iakovleva, A. V. (2009). Nominatsii lits po professional"noi prinadlezhnosti v sovremennom russkom iazyke [The nominations of persons on professional accessory in modern Russian]. PhD thesis. Yaroslavl. (In Russian) 
Ivanov, D. V. (2002). Virtualizatsiia obshchestva. Versiia. 2.0 [Virtualization of society. Version 2.0]. St. Petersburg. (In Russian)

Il'chenko, S. N. (2016). Feik v praktike elektronnykh SMI: kriterii dostovernosti [Fake in the practice of electronic media: criteria of reliability]. Mediaskop [Mediascope], 4. (In Russian)

Internet-kommunikatsiia kak novaia rechevaia formatsiia [Internet communication as new speech formation]. (2012). Moscow. (In Russian)

Issers, O. S. (2012). Kommunikativnye strategii i taktiki russkoi rechi [Communicative strategy and tactics of the Russian speech]. (6 ${ }^{\text {th }}$ ed.). Moscow. (In Russian)

Kutuzov, A. B. (2006). Model' funktsionirovaniia terminologicheskogo slengizma $v$ diskurse setevyh forumov [Model of functioning of a terminological slengizm in a discourse of network forums]. $\mathrm{PhD}$ thesis. Tyumen. (In Russian)

Likholitov, P. V. (1997). Komp'iuternyi zhargon [Computer slang]. Russkaya rech [Russian speech], 3, 43-49. (In Russian)

Maksimova, O.B. (2010). Iazyk v internet-kommunikatsii: obshchie zakonomernosti i natsional'nokul'turnye osobennosti (na materiale russkogo i angliiskogo iazykov) [Language in Internet communication: the general regularities and national cultural features (on the material of the Russian and English languages)]. Vestnik Rossiiskogo universiteta druzhby narodov. Seriya "Teoriia iazyka. Semiotika. Semantika" [Peoples' Friendship University of Russia (RUDN) Journal of Language Studies, Semiotics and Semantics], 3, 74-90. (In Russian)

Polonskii, A. V. (2016). Kul'turnyi status mediinogo teksta [Cultural status of the media text]. Medialingvistika [Media linguistics], 1 (11), 7-18. (In Russian)

Van Reenen, C. (2013). From Trolling for Newbs to Trolling for Cheezburger: An Historical Analysis of the Communicative Strategies of Trolling. Bowling Green, Ohio.

Riazantseva, T.I. (2010). Gipertekst i elektronnaia kommunikatsiia [Hypertext and electronic communication]. Moscow. (In Russian)

Shchipitsina, L.Yu. (2010). Kom’piuterno-oposredovannaia kommunikatsiia: lingvisticheskii aspekt analiza [The computer mediated communication: linguistic aspect of the analysis]. Moscow. (In Russian)

Received: May 15, 2018

Accepted: September 1, 2018

Author's information:

Alexander A.Malyshev — PhD in Philology; a.malyshev@spbu.ru

\section{Сетевые номинации субъекта медиаобщения в современном русском языке}

\section{A. А. Мальиев}

Санкт-Петербургский государственный университет,

Российская Федерация, 199004, Санкт-Петербург, 1-я линия В. О., 26

Для цитирования: Malyshev, А.А. (2018). Network nominations of media communication participants in the modern Russian language. Медиалингвистика, 5 (3), 339-345. https://doi.org/10.21638/ spbu22.2018.307

В статье рассматриваются примеры номинации участников современной медиакоммуникации как живого речетворческого процесса, происходящего в компьютерно опосредованном дискурсе Интернета, т.е. в виртуализованном социальном пространстве, отличающемся стремлением к максимальному диалогическому сближению действующих лиц. Интерактивность и вовлечённость всех участников сетевого взаимодействия в создание медиаконтента приводит к децентрализации коммуникации и превращению объекта медиакоммуникации в полноценный субъект, создает равноправие адресата и адресанта. Конвергентное пространство современной медиасреды, определяющее выбор участниками медиаобщения определенной речевой модели поведения, от- 
личается особой иерархией отношений коммуникантов в рамках субъект-объектного или субъект-субъектного диалогического взаимодействия. Коммуникация в когнитивно специфической среде медиареальности позволяет пользователям осмыслять и терминологически детерминировать роль каждой личности из числа встречающихся в сетевом пространстве (как уже известных им, так и встреченных впервые). В силу этого в некоторых случаях представляется затруднительным определить место субъекта медиаобщения в противопоставлении «любитель - профессионал» и квалифицировать его номинацию как номинацию общего рода или как профессионально обусловленную номинацию, что обусловливается самой дискурсивной средой существования медиареальности. Выделяются три вида номинации языковой личности в зависимости от ролевого участия номинируемого субъекта в процессе когнитивной идентификации (идентификация «изнутри», репрезентация «со стороны», самоопределение). Ставится вопрос о двойственности употребления отдельных номинаций вследствие влияния политико-идеологического аспекта в оценочном наименовании действий, что является одним из средств установления контакта с аудиторией. Отдельное внимание уделяется степени профессиональной вовлеченности субъектов медиаобщения в медиареальность и формированию негативных коннотаций у ряда обозначений коммуникантов по причине особенностей их сетевого поведения.

Ключевые слова: медиаобщение, сетевое общение, медиалингвистика, виртуальное общество.

Контактная информация:

Мальчев Александр Александрович — PhD in Philology; a.malyshev@spbu.ru 